Article

\title{
Utilizing HyspIRI Prototype Data for Geological Exploration Applications: A Southern California Case Study
}

\author{
Wendy M. Calvin * and Elizabeth L. Pace \\ Department of Geological Sciences and Engineering, University of Nevada, Reno, NV 89557, USA; \\ pacebetsy@gmail.com \\ * Correspondence: wcalvin@unr.edu; Tel.: +1-775-784-1785 \\ Academic Editors: Kevin Tansey, Stephen Grebby and Jesus Martinez-Frias \\ Received: 4 January 2016; Accepted: 12 February 2016; Published: 24 February 2016
}

\begin{abstract}
The purpose of this study was to demonstrate the value of the proposed Hyperspectral Infrared Imager (HyspIRI) instrument for geological mapping applications. HyspIRI-like data were collected as part of the HyspIRI airborne campaign that covered large regions of California, USA, over multiple seasons. This work focused on a Southern California area, which encompasses Imperial Valley, the Salton Sea, the Orocopia Mountains, the Chocolate Mountains, and a variety of interesting geological phenomena including fumarole fields and sand dunes. We have mapped hydrothermal alteration, lithology and thermal anomalies, demonstrating the value of this type of data for future geologic exploration activities. We believe HyspIRI will be an important instrument for exploration geologists as data may be quickly manipulated and used for remote mapping of hydrothermal alteration minerals, lithology and temperature anomalies.
\end{abstract}

Keywords: HyspIRI; AVIRIS; MASTER; geology; remote sensing; southern California; geothermal; mineral exploration; thermal anomaly

\section{Introduction}

Geologic exploration has taken advantage of satellite and airborne sensors to map structure, lithology and hydrothermal alteration for many decades (e.g., [1], and references therein). The launch of the Advanced Spaceborne Thermal Emission and Reflectance Radiometer (ASTER) [2] and Hyperion [3] instruments ushered in a new era of satellite remote sensing for geologic applications. ASTER has been widely used for lithologic and geologic studies (e.g., [4-8]), often in conjunction with airborne imaging spectrometer systems, such as the Advanced Visible/Infrared Imaging Specrometer (AVIRIS) or HyMap (e.g., $[9,10])$. Hyperion has received only limited attention for geologic applications, possibly due to the sparse global coverage [11] and the lower signal-to-noise ratio at wavelengths longer than $2.0 \mu \mathrm{m}$ [12], that are critical for mineral mapping. An additional hurdle to using Hyperion data is that it is provided in radiance, necessitating additional calibration to obtain at-surface reflectance for geologic studies.

Several efforts are currently underway to develop and launch the next generation of imaging spectrometer systems on satellite platforms for a wide range of Earth Observation goals. Many of these systems are confined to wavelengths less than approximately $1.0 \mu \mathrm{m}$, but several planned instruments include the full range up to $2.5 \mu \mathrm{m}$ and will be useful for geologic exploration. Canada's Hyperspectral Environment and Resource Observer (HERO) [13], Germany's Environmental Mapping and Analysis Program (EnMAP) [14], Japan's Hyperspectral Imager Suite (HISUI) [15], Italy's (PRecusore IperSpettrale della Missione Operativa) PRISMA [16] and the USA's Hyperspectral Infrared 
Imager (HyspIRI) [17] are in varying stages of study and development. EnMAP, HISUI and PRISMA are slated for launch in 2017 or later. HyspIRI is the only mission concept that includes both shortwave and thermal infrared channels, similar to ASTER.

HyspIRI was a mission recommended in the 2007 NASA Earth Science decadal survey, but has not yet been approved for a new mission start. The instrument would have $10 \mathrm{~nm}$ contiguous spectral channels from 0.38 to $2.5 \mu \mathrm{m}$ (>200 channels) with a 30-m spatial resolution and a 16-day revisit rate. In addition, the HyspIRI instrument will have eight bands in the thermal infrared (TIR) from 4 to $13 \mu \mathrm{m}$ with 60-m spatial resolution and a five-day revisit rate. Additional information on the mission architecture, planned on-board processing, and applications is provided by Lee et al. [17]. To demonstrate the effectiveness of the HyspIRI instrument for science applications NASA funded the HyspIRI airborne campaign whereby radiance data were collected via aircraft and used to generate Level 2 HyspIRI-like reflectance, emissivity, and land surface temperature data. Our funded investigation was to assess the utility of HyspIRI-like data for a variety of geologic applications including mineral and energy exploration, impacts of resource development, and natural hazards. The goal of this study was to assess the utility of several standard derived data products for geological assessments.

For various environmental and ecosystem applications, the HyspIRI airborne campaign data were collected during spring, summer, and fall of 2013, 2014, and 2015. Data were collected over the same five regions ("boxes") within the state of California, USA, each time: Southern California, Santa Barbara, San Francisco Bay, Yosemite, and Lake Tahoe. Both the AVIRIS and MODIS/ASTER Airborne Simulator (MASTER) instruments were flown at $20 \mathrm{~km}$ above ground level onboard NASA's ER-2 aircraft [17]. AVIRIS collects 224 contiguous spectral channels from 0.4 to $2.5 \mu \mathrm{m}$ [18] and MASTER collects 50 channels from 0.4 to $13 \mu \mathrm{m}$, though our study uses only the channels from 7.5 to $13 \mu \mathrm{m}$ [19]. AVIRIS is considered a spectral analog for HyspIRI so no wavelength resampling is performed. AVIRIS collected Level 1 radiance data at $18 \mathrm{~m}$ resolution. Level 2 simulated reflectance data were generated by the AVIRIS team at 18- and 30-m resolutions, as described in Section 3. Planned band centers for the seven HyspIRI TIR channels, from 7 to 13, are offset from MASTER, and MASTER has additional channels at 9.6, 10.1, and 12.8 (Table 1). We did not resample MASTER data to the planned HyspIRI wavelengths, but the temperature-emissivity separation (TES) product generated by the team includes only five channels of which band centers roughly correspond to those planned for HyspIRI (Table 1). MASTER collected Level 1 radiance data at 60-m resolution, which were converted to Level 2 temperature and emissivity products as described in Section 3. Data were generally collected during cloud-free days at high sun-angle hours, but data were also collected over the Southern California box during two nighttime flights as per special request. The focus area for this study is shown in Figure 1; it includes the southeast end of the Southern California data collection box. This region includes the Salton Sea, Imperial Valley, the Orocopia Mountains, and the Chocolate Mountains, which are just north of the US-Mexico border.

Table 1. Band centers in $\mu \mathrm{m}$ for the TIR region for HyspIRI, ASTER, MASTER.

\begin{tabular}{ccccc}
\hline HyspIRI [17] & ASTER Channel [6] & ASTER Wavelength [6] & MASTER $^{\mathbf{1}}$ & MASTER-TES Processed \\
\hline 7.35 & - & - & - & - \\
- & - & - & 7.8 & - \\
8.28 & 10 & 8.3 & 8.18 & - \\
8.63 & 11 & 8.65 & 8.62 & 8.6 \\
9.07 & 12 & 9.1 & 9.06 & 9.03 \\
- & - & - & 9.67 & - \\
- & - & - & 10.10 & - \\
10.53 & 13 & 10.6 & 10.59 & 10.63 \\
11.33 & 14 & - & 11.33 & 12.32 \\
12.05 & - & - & 12.12 & - \\
- & - & - & 1.36 & 12.1 \\
\hline
\end{tabular}

1: MASTER as flown on 9/24/2013 from the on-line calibration files available on line [19]. 


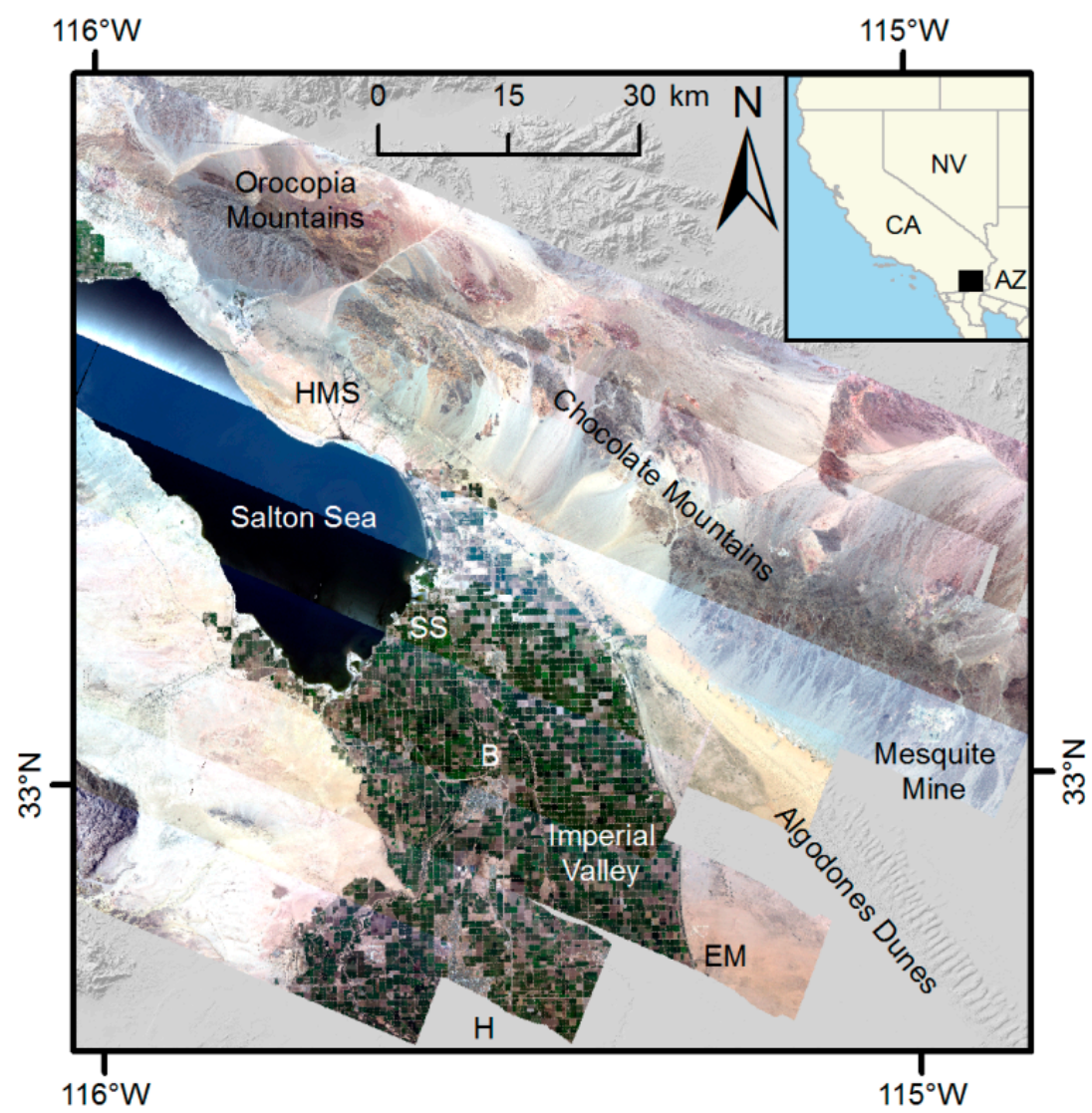

Figure 1. Imperial Valley, California, USA, study area. A true color image derived from 18-m AVIRIS data is shown overlain on a topographic shaded relief image. Known geothermal resource areas or power plants are indicated by initials: HMS—Hot Mineral Spa; SS—Salton Sea; B—Brawley; EM-East Mesa; H-Heber. The inset on upper right map shows the location of the study area.

\section{Geologic Setting}

The Southern California box covers land from the US-Mexico border to the Los Angeles Basin but for this study we focused only on the part from the border to the north shore of the Salton Sea (Figure 1). We chose this area to study because of the variety in land surface cover and the abundance of interesting geological phenomena, including diverse ages and lithologies of bedrock exposures, an active open pit gold mine, many geothermal energy production sites, active fumarolic and gas emissions from current hydrothermal activity, recent volcanic eruptions and the potential for both natural and induced seismic hazards. A geologic map generalized from Jennings et al. [20] is shown in Figure 2.

The northwest-trending Chocolate Mountains mark the eastern boundary of Imperial Valley. The range is predominantly composed of Precambrian igneous and metamorphic rocks, Pre-Cretaceous metasedimentary rocks, Mesozoic granitic rocks, and Tertiary volcanic rocks [21]. The Chocolate Mountains contain the Chocolate Mountain Aerial Gunnery Range, which is used by the Navy and Marines and not accessible to the public, but is an area of potential geothermal energy development by the US Navy [22]. New Gold Inc.'s Mesquite Mine sits at the southeast corner of the Southern California box. The fault-controlled epithermal gold deposit is hosted within Mesozoic gneisses where gold occurs both disseminated and in veins [23]. The region around this open pit mine was the focus of a remote sensing study conducted by Zhang et al. [8] who used ASTER data to remotely map alteration mineralogy, specifically alunite, kaolinite, montmorillonite, and muscovite. 


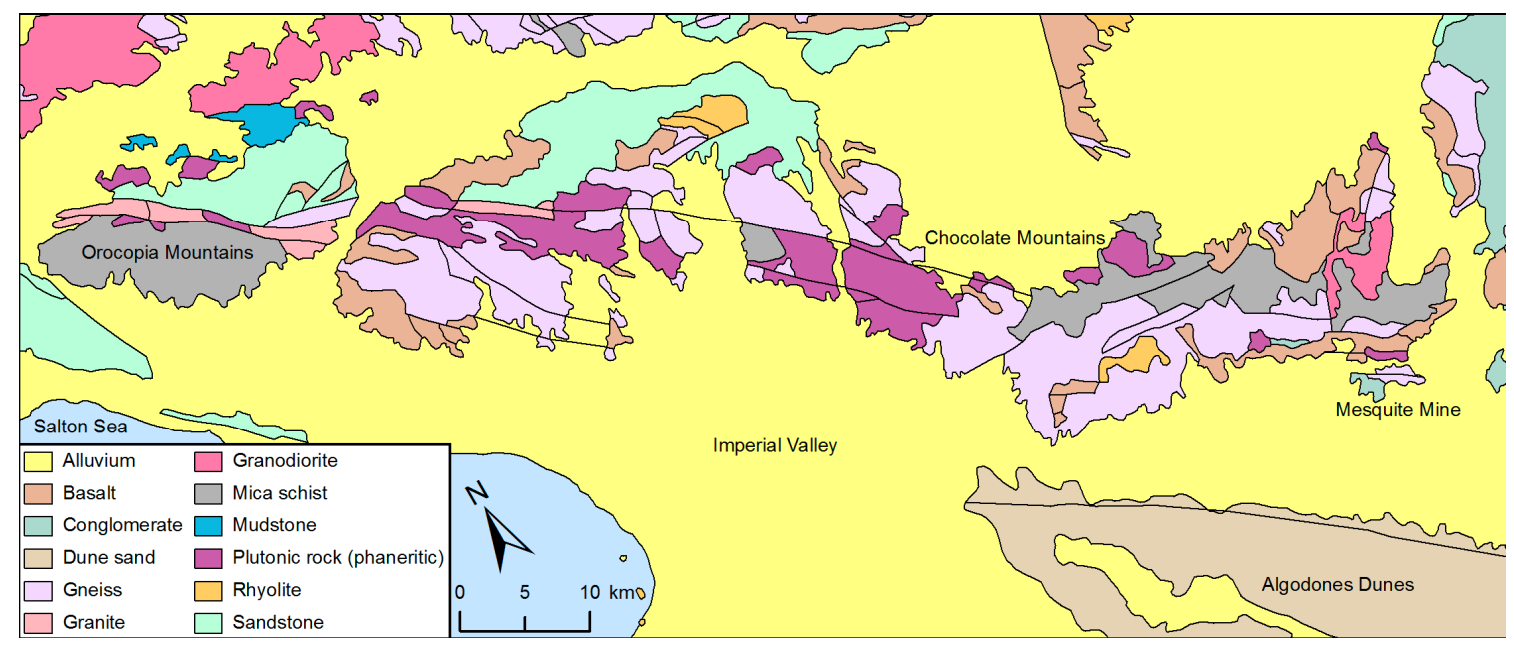

Figure 2. Orocopia Mountains and Chocolate Mountains geologic map showing major lithologic units from Jenings et al. [20].

To the northwest of the Chocolate Mountains are the Orocopia Mountains, composed of the Late Cretaceous-Early Cenozoic Orocopia Schist. The Orocopia Schist is particularly interesting because it was subducted at a low angle beneath the North American plate during the Laramide Orogeny and exhumed during middle Cenozoic extension of the region [24]. Additionally of interest in the region are the Algodones Dunes, a $70 \mathrm{~km}$-long sand dune field that occupies the southeastern part of Imperial Valley. Algodones dune sand is likely derived from the beaches of ancient Lake Cahuilla, a lake that formed in the geologic past whenever the Colorado River flowed into Imperial Valley instead of the Gulf of California [25]. The Salton Sea now occupies part of the region once filled by Lake Cahuilla.

Imperial Valley is one of the most prolific geothermal power production locations in California. Three electricity-producing geothermal fields are covered by the Southern California box: Salton Sea, East Mesa, and North Brawley (Figure 1). Several other geothermal fields exist in the region and are in various stages of use and development. Hot springs line the northwestern front of the Chocolate Mountains; some are used for spas and hot spring resorts at the Hot Mineral Spa area. Surface indicators of the geothermal activity near the south shore of the Salton Sea include the Davis-Schrimpf field where hot water seeps from the surface to form muddy pools and gryphons. The Imperial $\mathrm{CO}_{2}$ field is located to the north of these mudpots, where so much $\mathrm{CO}_{2}$ is emitted that a dry ice production facility was operated from 1933 to 1954 . As the Salton Sea water level continues to drop, more mudpots, gryphons, and fumaroles are being exposed, for example along the edge of the lake near Mullet Island where exposure began in 2007 [26]. Lynch and Hudnut [27] surveyed other recently exposed geothermal features within the Wister Unit of the Imperial Wildlife Area. The Mullet Island and Wister fumarole fields define lineaments interpreted to be the Calipatria Fault [26] and an extension of the San Andreas Fault [27], respectively. Reath and Ramsey [28] used airborne Spatially Enhanced Broadband Array Spectrograph System (SEBASS) data $(7.6-13.5 \mu \mathrm{m})$ data to map geothermal indicator minerals in this region, and Tratt et al. [29] used SEBASS data to map ammonia plumes and surface temperature. Ammonia emissions are likely derived from geothermal fluids moving through decomposing agricultural runoff and organic material [29].

Five northeast-trending volcanic domes are located at the southern shore of the Salton Sea. These rhyolitic domes, known as the Salton Buttes, were extruded between $c a .5900$ and 500 years [30,31]. The locations of young volcanism and geothermal fields are a result of the regional tectonics: the Salton Sea sits in a pull-apart basin which opened within the Brawley Seismic Zone, a stepover between the strike-slip Imperial fault and San Andreas Fault [32]. The San Andreas Fault zone runs along the eastern shore of the Salton Sea. The area is host to abundant natural seismicity [33], as well as injection related seismicity [34]. 


\section{Materials and Methods}

All analyses used data from the 2013 suite of flights as these were corrected by the AVIRIS and MASTER teams and were used to create the HyspIRI simulated products including at-surface reflectance at several spatial scales, land surface temperature and emissivity [35-37]. Apparent surface reflectance is generated using the ATREM atmospheric correction [35]. The $30 \mathrm{~m}$ products were resampled using Gaussian weighted sampling with a $30 \mathrm{~m}$ full-width half-maximum over a $90 \mathrm{~m}$ by $90 \mathrm{~m}$ area. Noise approximating a HyspIRI VSWIR noise function was added to radiance data [36]. Temperature-emissivity separation takes advantage of concurrent water vapor estimates obtained from the AVIRIS sensor to improve land surface temperature [37].

\subsection{VSWIR Decorrelation Stretch to Quickly Identify Alteration}

Both modern geothermal systems and fossil hydrothermal systems associated with ore bodies commonly display alteration mineralogy at the surface. We advocate a quick method for rapidly locating alteration minerals is a simple decorrelation stretch (DCS) of SWIR bands at 2.16, 2.21, and $2.24 \mu \mathrm{m}$ displayed as red, green, and blue (RGB), respectively. The DCS technique removes correlation between channels and creates a highly saturated color image, and while these band centers are similar to those in ASTER and World View 3 sensors, those multichannel instruments have much broader band passes. Using the $10 \mathrm{~nm}$ narrow spectral channels of the AVIRIS instrument allows this technique to separate common alteration minerals based on their band centers (Figure 3), so that specific mineral groups are highlighted in distinct colors, as demonstrated by Littlefield and Calvin [38]. This method can be performed quickly to generate an image that highlights common alteration minerals associated with argillic, phyllic, or propylitic alteration. Kaolinite and alunite are common argillic alteration products, formed where acidic fluids chemically weather country rock or occur near fumaroles. Muscovite and illite are low temperature phyllic alteration minerals. Chlorite commonly occurs in the propylitic alteration of mafic minerals and calcite can occur in propylitic alteration but may also be deposited around hot springs as travertine or tufa. Opal (amorphous silica) is deposited around hot springs as sinter. Using this simple color stretch, kaolinite and alunite are blue, muscovite and illite are magenta, chlorite and calcite are yellow, epidote is yellow-green, and opal is orange (Figure 3, [38,39]). The simplicity of this method promotes rapid assessment over large areas to help target the highest priority areas of interest. This decorrelation stretch technique was performed on the $18 \mathrm{~m}$ and $30 \mathrm{~m}$ Level 2 ortho-reflectance data collected by AVIRIS. We chose to use both the higher and lower spatial resolution data in order to compare results and assess what information might be lost at the proposed HyspIRI spatial resolution.

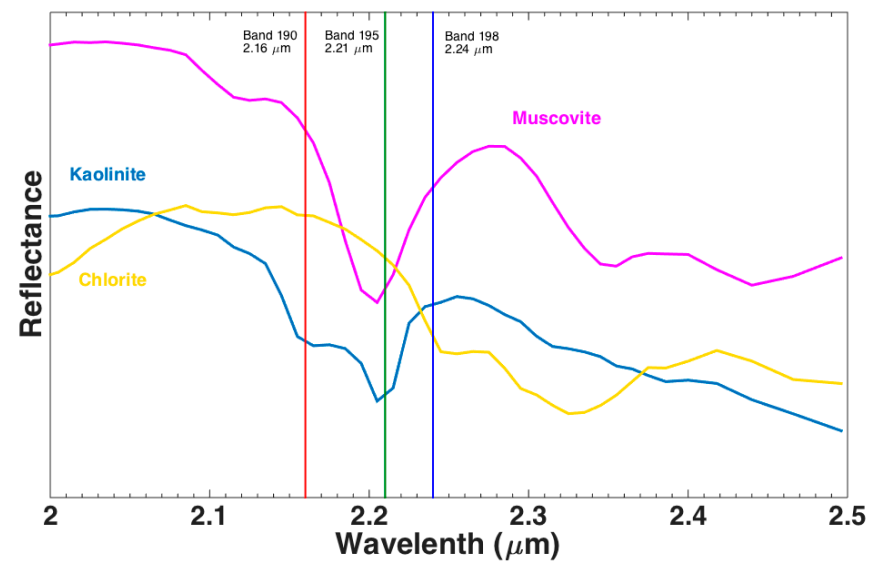

Figure 3. Illustration of a simple color decorrelation stretch band combination that rapidly separates common alteration minerals into distinct color fields. Red-Green-Blue channels are chosen as illustrated in the figure, and resulting mineral color associations are described in the text. Spectral standards are from the USGS spectral library [39]. 


\subsection{VSWIR Data for Mineral Mapping}

Kruse et al. [40] tested the ability of the HyspIRI instrument to discriminate various minerals at a 60-m spatial resolution over Cuprite and Steamboat Springs, Nevada, and Yellowstone, Wyoming. Recent developments in instrument design would improve the spatial resolution of the VSWIR range to $30 \mathrm{~m}$ [17]. The DCS color image described in the previous section quickly highlighted several regions with diverse alteration mineralogy. Detailed mineral mapping efforts were then focused on the Orocopia and Chocolate Mountains. We used 30-m AVIRIS Level 2 ortho-reflectance data for mineral mapping to test mapping abilities at the proposed spatial resolution. In our past remote sensing efforts focused on geothermal indicator minerals, techniques included a combination of statistical methods and experience-based approaches to map mineralogy. This methodology has worked well over a wide range of targets in the arid southwest of the USA [41]. We also used the standard spectral hourglass approach included in the ENVI software, which involves a Minimum Noise Fraction (MNF) transformation and Pixel Purity Index (PPI) algorithm. Ultimately we used carefully chosen threshold values to select pixels from Matched Filter images as mineral classes. These classes were bought into ArcGIS for interpretation with existing geologic maps.

\subsection{TIR Decorrelation Stretch to Quickly Identify Lithology}

MASTER TIR data were provided as a Level 2 emissivity product. Two different DCS approaches to TIR data have been used in previous studies [6,42]. We examined both these decorrelation stretches to highlight different lithologies within the Orocopia and Chocolate Mountains. The first technique is derived from Rowan and Mars [6] who used a decorrelation stretch of ASTER bands 13, 12, 10 that roughly correspond to channels $10.63,9.03$, and $8.60 \mu \mathrm{m}$ displayed as RGB, respectively, to guide lithologic mapping near Mountain Pass, California. Another DCS combination was proposed by Vaughan et al. [42] who used 11.32, 10.66 and $9.08 \mu \mathrm{m}$ as RGB. Both of these color products will highlight quartz-rich rocks separately from those that are more altered or intermediate in composition. These color stretches on the Salton regional area were transferred to ArcGIS where lithologies could be compared to the geologic units of Jennings et al. [20].

\subsection{TIR Emissivity Data for Lithologic Mapping}

Several previous studies have used the emissivity spectra from ASTER to map lithologic units [6,42-45]. Mineral spectral shapes in ASTER and HyspIRI prototype data are subdued as the five channels are really insufficient to uniquely and diagnostically identify mineralogy $[28,42]$. While spectra of minerals and field samples convolved to ASTER band passes show diverse characteristics [44,45], actual ASTER data primarily maps units through the relative strength of emissivity near $9 \mu \mathrm{m}$ [43-45] and lower emissivity at 8.3 and $8.6 \mu \mathrm{m}$ (channels 10 and 11). We used the DCS methods described above along with the geologic map to identify regions of interest where unique spectral shapes were identified and mapped spectral shapes using spectral similarity tools, such as the spectral angle and matched filter.

\subsection{TIR Data for Thermal Anomaly Identification}

Two special nighttime flights were flown to collect MASTER data over the Imperial Valley. We chose to use the data from the flight on 1 June 2013 because of its slightly better spatial coverage. It can be difficult to produce accurate land surface temperature maps from daytime data due to shading and albedo, but even nighttime remote sensing data are affected by elevation, aspect, and slope. The most accurate detection of thermal anomalies includes day/night image pairs and must account for surface thermal inertia (e.g., [46]). We wanted to explore how well the standard land surface temperature product would be able to identify the localized thermal anomalies without additional processing in a small area within Imperial Valley at the $60-\mathrm{m}$ spatial resolution. This area is at the southern end of the Salton Sea, covering known mudpots and fumarolic vents and at a nearly constant elevation below $100 \mathrm{~m}$. Using ArcGIS we made comparisons with previous results [26,27,29]. 


\section{Results}

\subsection{VSWIR Decorrelation Stretch to Quickly Identify Alteration}

A decorrelation stretch of AVIRIS bands at 2.16, 2.21, and $2.24 \mu \mathrm{m}$, displayed as RGB, respectively, was used to quickly identify areas of hydrothermal alteration (Figure 4). As mentioned in Section 3.1, this decorrelation stretch typically highlights kaolinite, alunite, muscovite, illite, chlorite, epidote, calcite, and opal. We found that both the 18-m and 30-m images highlighted these minerals well and that the 30-m DCS image is very similar to the 18-m DCS image in the distribution of colors. The 30-m DCS image generally shows sharper color changes because the larger pixel size does not permit showing subtle color gradation as well.

As the Chocolate Mountains are off-limits to public access, the colors in the DCS images were validated using the full spectral data (see also Section 4.2). These DCS images highlighted kaolinite in blue. Kaolinite was distributed throughout much of the Chocolate Mountains and Orocopia Mountains. Blue also highlighted the alunite in the scene, a very small area west of the Salton Sea near the western-most corner of the black box in Figure 4. Magenta was generally muscovite, and yellow-green was epidote. These minerals occurred within the Chocolate Mountains and Orocopia Mountains. We identified calcite highlighted by yellow in the southwest corner of Figure 4 within a sandstone/mudstone unit. The colors in the DCS images clearly highlighted hydrothermal alteration mineral occurrences when compared against the full spectral profiles for these regions. From previous experience $[38,41]$ we know that this decorrelation stretch would highlight opal as orange, however there is no remotely sensed opal in the Imperial Valley. Orange hues on the eastern side of the scene are generally alluvium or undifferentiated soils.
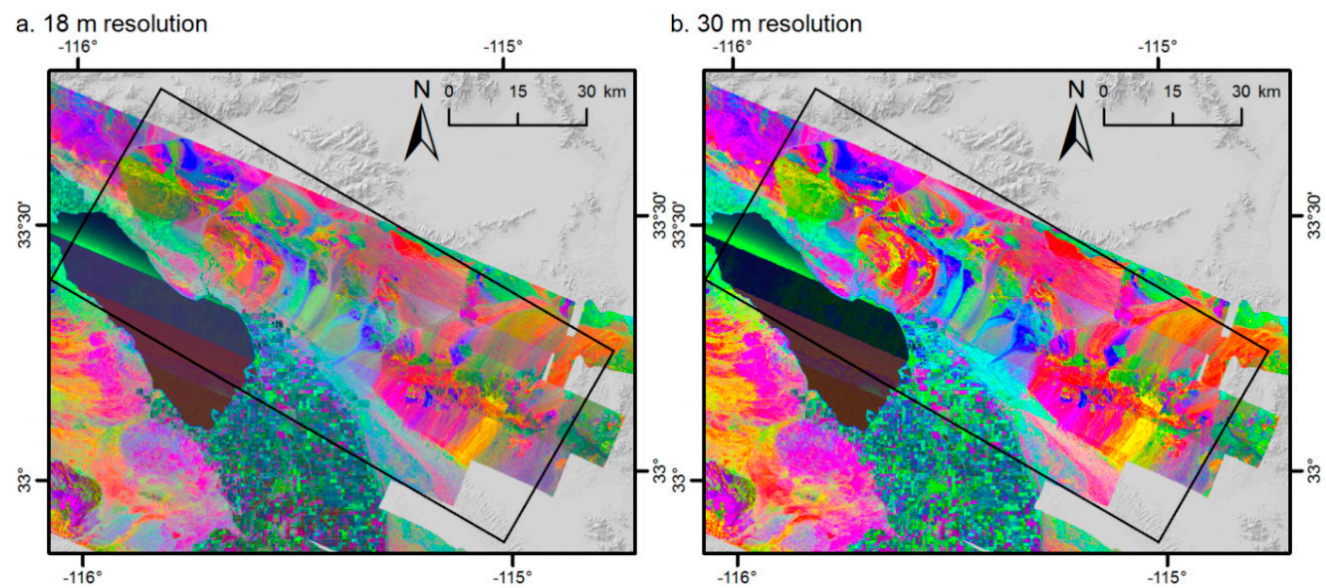

Figure 4. Decorrelation stretch of AVIRIS bands at 2.16, 2.21, and $2.24 \mu \mathrm{m}$ displayed as RGB, respectively. The same scene is shown at two different spatial resolutions: (a) $18 \mathrm{~m}$, the resolution of original AVIRIS data; and (b) $30 \mathrm{~m}$, the resolution of the proposed HyspIRI VSWIR data. The black box shows the location of Figure 5. Blues, magentas, and yellows highlight hydrothermal or other alteration mineralogy, as described in the text.

\subsection{VSWIR Data for Hydrothermal Alteration Mapping}

Using the 30-m VSWIR data collected by AVIRIS the matched filter classes remotely mapped epidote, muscovite, and kaolinite in the Orocopia Mountains and the Chocolate Mountains (Figure 5). Epidote was mapped within the Orocopia Schist, which agrees with the geologic description of the schist [24]. Intrusive rocks in the Orocopia Mountains showed epidote, muscovite, and kaolinite, which are interpreted to be the result of hydrothermal alteration. Kaolinite was also mapped within Cenozoic sedimentary units, including the Diligencia Formation and Maniobra Formation, both in the Orocopia Mountains. In the Chocolate Mountains, kaolinite and muscovite were primarily mapped 
within granites and Tertiary volcanic rocks. Using tight thresholds for the standard deviations on the mapped spectral classes, we did not identify opal, calcite, chlorite, or alunite to the east of the Salton Sea in the area subset of Figure 5. Figure 6 shows spectra of the mapped units compared with library mineral standards.

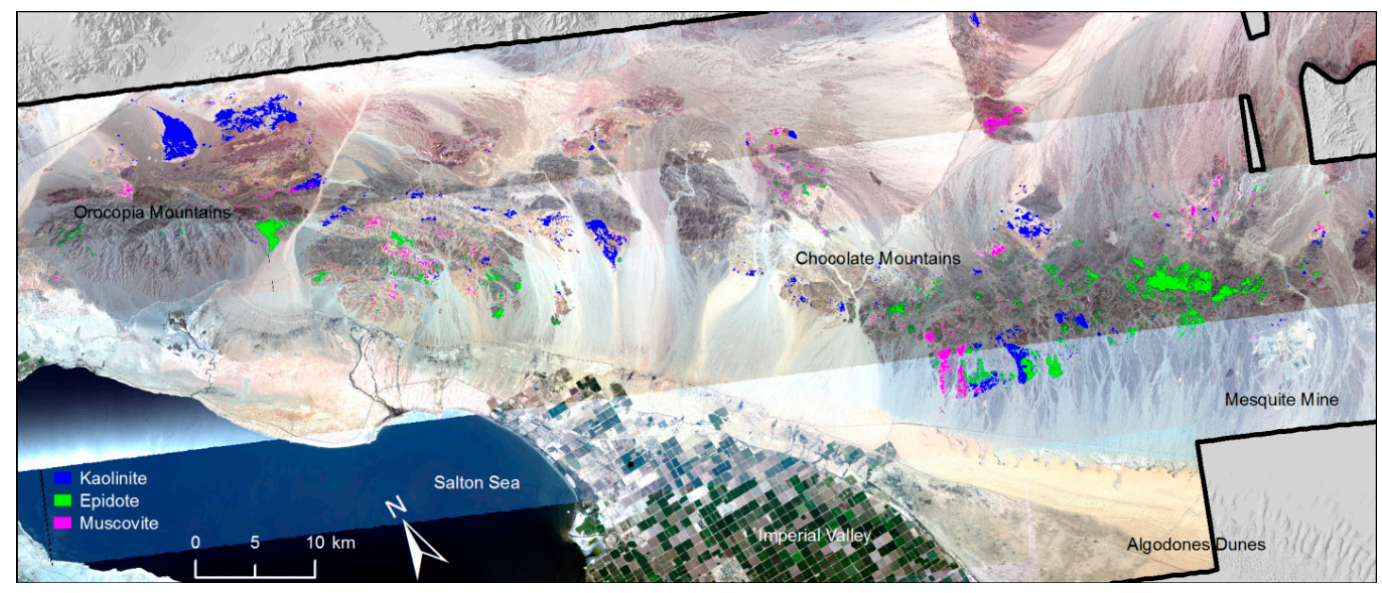

Figure 5. The Orocopia and Chocolate Mountains area. A true color image derived from $18 \mathrm{~m}$ AVIRIS data is shown overlain on a shaded relief image. Remotely mapped minerals are shown in colors: green-epidote; magenta-muscovite; blue-kaolinite. The location of this figure is shown in Figure 4.

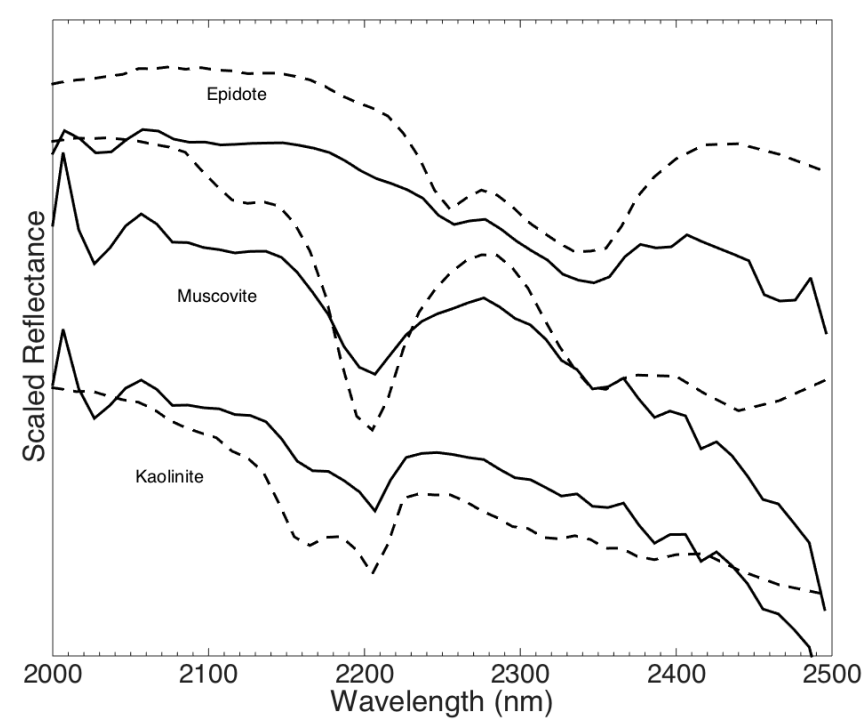

Figure 6. Spectra of mapped units (solid lines) compared with library mineral standards from the USGS spectral library [39] (dashed lines). Each scene spectrum represents an average of more than several hundred pixels.

\subsection{TIR Decorrelation Stretch to Quickly Identify Lithology}

A decorrelation stretch of MASTER bands at 10.63, 9.03, and $8.60 \mu \mathrm{m}$ displayed as RGB, respectively, was used for basic lithologic mapping (Figure 7). Similar to [6], we found that red pixels in the DCS image highlight quartz-rich units, for example the Algodones dune sand. Magenta highlighted schist and gneiss, which have relatively less quartz, for example the Orocopia Schist within the southern part of the Orocopia Mountains. We found that other units (basalt, sedimentary rocks, granite, granodiorite, rhyolite) did not necessarily correlate with colors in either of the DCS stretches. 


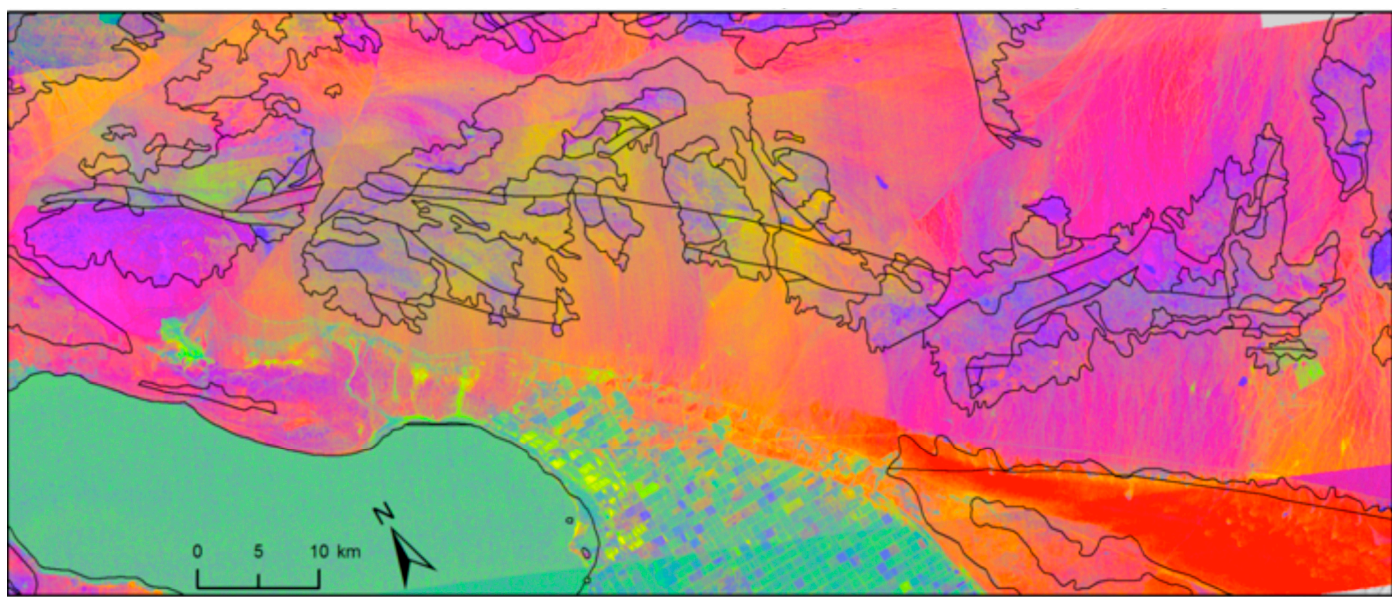

Figure 7. The Orocopia Mountains and the Chocolate Mountains. Decorrelation stretch of MASTER bands at 10.63, 9.03, and $8.60 \mu \mathrm{m}$ displayed as RGB, respectively. Geologic map units from Figure 2 are outlined by black lines. The location outline is shown in Figure 4.

\subsection{TIR Emissivity Data for Lithologic Mapping}

Because colors in the DCS were not well correlated with unit boundaries, we used color transitions, the geologic map, and other knowledge based approaches to identify regions with contrasting emissivity spectral shapes. Similar to other past studies, emissivity variability is primarily controlled by strength of the feature at $9.03 \mu \mathrm{m}$, with small changes in slope at $8.6 \mu \mathrm{m}$. The distinct spectral shapes identified are shown in Figure 8. Using spectral similarity tools such as a matched filter, the mica schist of the Orocopio Mountains and a small eastern outlier are mapped, along with several basalt units. However the majority of the Chocolate Mountains gneiss and granite units are not distinguished. The quartz sands of the Alogodones dune field are clearly distinguished using this technique.

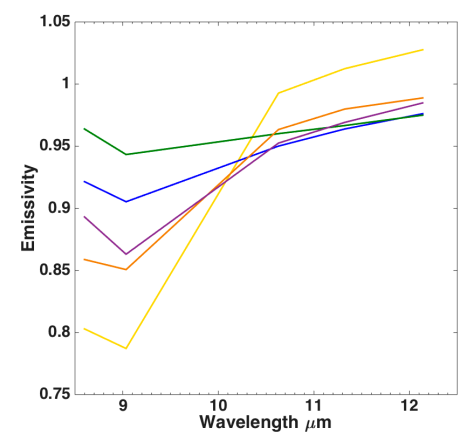

(a)

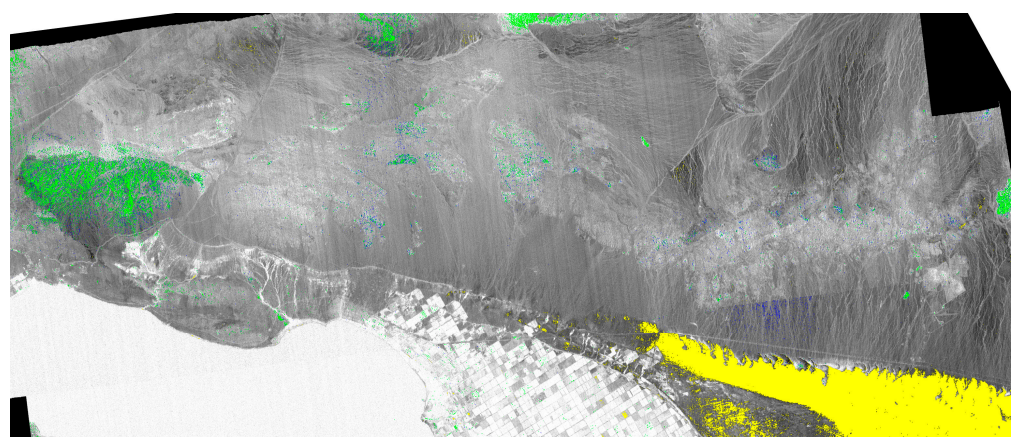

(b)

Figure 8. Emissivity spectral shapes (a) and spectral locations mapped; (b) using a matched filter approach. Colors in the map correspond to the same color in the spectral plot. Blue, green and purple spectral shapes occur in the same regions, identify the schist of the Orocopio Mountains, and several basalt outcrops. Yellow and coral spectral shapes both map the Algodones dune field and only yellow is shown for simplicity. The area shown is identified in Figure 4 and is the same as in Figures 5 and 7 for units compare with Figures 2 and 7.

\subsection{TIR Data for Thermal Anomaly Identification}

We focused our study of the land surface temperature data collected by MASTER on an area at the southern end of the Salton Sea at elevations below $100 \mathrm{~m}$. Temperatures ranged from 16.85 to $47.85^{\circ} \mathrm{C}$ $\left(62.33\right.$ to $\left.118.13^{\circ} \mathrm{F}\right)$ and the relative scale of temperature variation appeared valid. Within Salton Sea there are areas of cooler water near the inflow of the Alamo and New Rivers, which appear cyan-blue 
in Figure 9. The agricultural area in Imperial Valley is generally cool due to the crops, which retain water and provide shade during the day (blue in Figure 9).
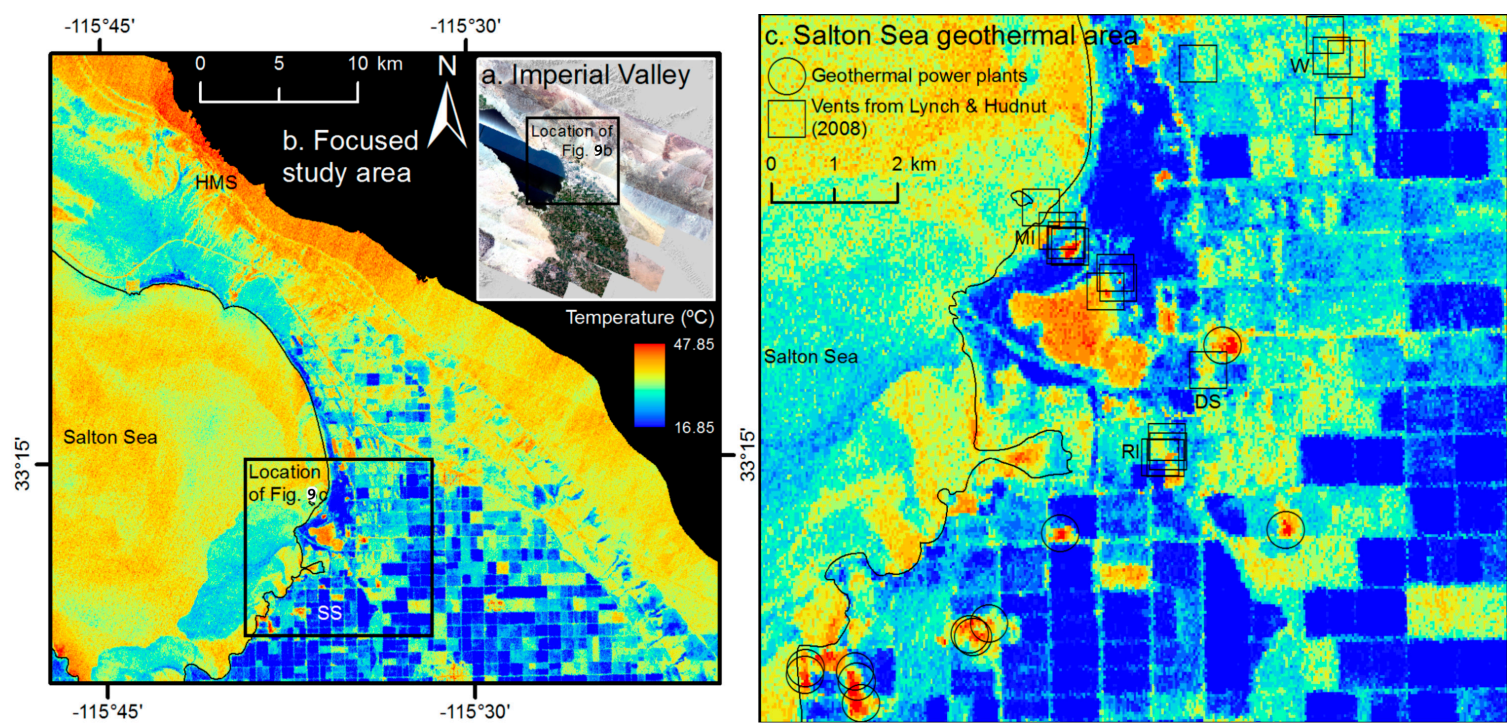

Figure 9. (a) Imperial Valley, California study area. A true color image derived from AVIRIS data is shown overlain on a shaded relief image; the box shows the location of (b). (b) Land surface temperature data for the southern end of the Salton Sea below $100 \mathrm{~m}$ elevation; the box shows the location of (c). Known geothermal areas are indicated by initials: HMS-Hot Mineral Spa; SS—Salton Sea. (c) Land surface temperature data for the Salton Sea geothermal area. Circles show geothermal power plants and squares show geothermal features located by [27]. Fumarole fields are indicated by initials: W—Wister; MI—Mullet Island; DS—Davis Schrimpf; RI—Red Island.

Thermal anomalies occur within the Salton Sea geothermal area (red in Figure 9c). Some of the anomalies correlate with the locations of geothermal power plants. Geothermal power plants utilize condensers, whereby large volumes of hot fluids are run through cooling towers to release heat. Ten individual condenser units occur in this region and were associated with thermal anomalies (circles in Figure 9). Other thermal anomalies correlate with the vents identified by [26,27]. Two of the strongest anomalies highlight recently exposed fumarole fields near Mullet Island. The shape of the larger of these thermal anomalies agreed with the results from [29] who mapped it using $1 \mathrm{~m}$ spatial resolution SEBASS data. Many of the nearly twenty individual geothermal features noted by [27] (squares in Figure 9c) are small or not very active. Approximately one-half of the features previously identified do not appear anomalous in this one night-time scene. One example is the western-most Wister area vent shown in Figure 9c, which the authors describe as a "bulldozed ring in pond" ([27], page 1722). This feature is not likely very active if a bulldozer was able to drive through it, and not surprisingly there is no significant thermal anomaly shown in the TIR data for this location.

There are several thermal anomalies shown in the TIR data that are not correlated with geothermal power plants or known geothermal features. The anomalies near Mullet Island are associated with a shallow pond where water is solar heated to high temperatures. Other anomalies could be associated low albedo as there is great variation in field cover (different crops at different stages of growth, and some fallow fields). However there are a few remaining thermal anomalies that could be associated with previously unrecognized or shifting sources of surface heat flux and would be places for future field validation. 


\section{Discussion}

\subsection{Hydrothermal Alteration Mapping}

The decorrelation stretch of AVIRIS bands at 2.16, 2.21, and $2.24 \mu \mathrm{m}$ quickly identified regions where hydrothermal alteration minerals occur. In particular, alunite, calcite, epidote, muscovite and kaolinite locations were validated using the full spectral properties of the data set. The rapid identification of these minerals is useful to both the geothermal and economic mineral industries because (advanced) argillic alteration (alunite and kaolinite) is an excellent indicator of hydrothermal fluid movement.

Using a combination of the DCS images and statistical methods, the 30-m HyspIRI-like VSWIR data were used to successfully map epidote, muscovite, and kaolinite within the Orocopia Mountains and Chocolate Mountains. The detailed mapping showed good correspondence with the simple DCS technique, though smaller areas were mapped by using tight tolerances on mineral spectral matches. We interpret that the epidote mapped within gneiss and schist is likely of metamorphic origin, however the kaolinite and muscovite may be hydrothermal in origin. In general, there is a good correspondence between the locations where we identified strong hydrothermal mineral abundance and the alteration zones identified in ASTER data by Zhang et al. [8] (Figure 8). We did not map either alunite or montmorillonite in the HyspIRI-like data, which was identified by [8]. The areas mapped by [8] as alunite were identified as kaolinite. We also did not identify the extensive montmorillonite mapped by Zhang et al. [8] and they did not map epidote. These discrepancies in mineral mapping are likely because [8] used multi-channel ASTER data and we used the much higher spectral resolution data of the HyspIRI-like reflectance product, with tight tolerances on similarity to mineral spectral features.

\subsection{Lithologic Mapping}

We used two decorrelation stretches of MASTER bands to quickly differentiate lithologies in the Imperial Valley, but ultimately found that this method was only able to reliably highlight quartz-rich areas. The various combinations showed the Algodones dune sand and the Orocopia Schist but did not highlight other igneous and sedimentary units. Using a knowledge-based approach, five different emissivity shapes were identified and mapped using spectral similarity tools. The spectra also matched the dune field, and the Orocopoia schist. The spectra also mapped several basalt outcrops but did not distinguish the units of the Chocolate Mountains. In order to achieve the best lithologic mapping, the complementary nature of the VSWIR and TIR channels will need to be employed, similar to past successful studies with ASTER [43-45,47,48].

\subsection{Thermal Anomaly Mapping}

We found that the Level 2 land surface temperature nighttime image derived from MASTER TIR data identified numerous thermal anomalies. Most of the strongest thermal anomalies highlighted geothermal power plants, with other anomalies highlighting fumarole fields. Of the many naturally occurring small anomalies previously identified, many features were not evident at the proposed 60-m HyspIRI TIR resolution. However, all power plant condenser units were correlated with thermal anomalies. The largest and recently exposed fumarole fields near Mullet Island would be identified in the 60-m HyspIRI data. The high temporal resolution of HyspIRI is well suited to study a place like the Salton Sea where new geothermal features are being exposed on the order of months to years.

\section{Conclusions}

In this study we demonstrated the geological applications of HyspIRI-like data in the Imperial Valley region of Southern California. We used a decorrelation stretch of SWIR bands to quickly highlight hydrothermal alteration, and a decorrelation stretch of TIR bands to quickly highlight quartz-rich units. We used DCS images to guide mineral mapping efforts. Using the VSWIR data we were able to explicitly map the hydrothermal alteration minerals present in the scene: epidote, 
muscovite, and kaolinite. TIR mapping highlighted quartz rich sands, schist and some basalt outcrops. We also used land surface temperature data derived from the TIR data to identify thermal anomalies, which were associated with geothermal power plants, fumarole fields, and shallow ponds.

We advocate that HyspIRI will be a useful instrument to the geology community, especially to those interested in mineral distribution, for example in geothermal and mineral exploration. The high resolution of the VSWIR data allows for identification of very specific mineralogy with narrow absorption features. The $30 \mathrm{~m}$ spatial resolution of the VSWIR data is high enough to map relatively small mineral occurrences and rock outcrops, for example, the Salton Buttes. The 60-m resolution of the TIR data is high enough to distinguish some geologic units and identify small thermal anomalies such as the Wister fumarole fields. The 5- and 16-day revisit time for the TIR and VSWIR instruments, respectively, will provide high temporal resolution for the monitoring of rapidly changing geologic conditions, for example the continued exposure of new fumarole fields as the Salton Sea continues to recede.

Acknowledgments: This work was supported by NASA Grant \#NNX12AQ17G to UNR. Derived data product support from NASA Grant \#NNX12AP08G.

Author Contributions: Elizabeth Pace performed the VSWIR analysis and drafted the initial version of the manuscript. Wendy Calvin performed the TIR analysis and mapping and wrote the final version of the text.

Conflicts of Interest: The authors declare no conflict of interest.

\section{Abbreviations}

The following abbreviations are used in this manuscript:

$\begin{array}{ll}\text { ASTER } & \text { Advanced Spaceborne Thermal Emission and Reflectance Radiometer } \\ \text { AVIRIS } & \text { Advanced Visible/Infrared Imaging Specrometer } \\ \text { DCS } & \text { decorrelation stretch } \\ \text { HyspIRI } & \text { Hyperspectral Infrared Imager } \\ \text { MASTER } & \text { MODIS/ASTER Airborne Simulator } \\ \text { TIR } & \text { Thermal Infrared } \\ \text { VSWIR } & \text { Visible and Short-Wave Infrared }\end{array}$

\section{References}

1. Sabins, F.F. Remote sensing for mineral exploration. Ore Geol. Rev. 1999, 14, 157-183. [CrossRef]

2. Yamaguchi, Y.; Kahle, A.B.; Tsu, H.; Kawakami, T.; Pniel, M. Overview of Advanced Spaceborne Thermal Emission and Reflection Radiometer (ASTER). IEEE Trans. Geosci. Remote Sens. 1998, 36, 1062-1071. [CrossRef]

3. Pearlman, J.S.; Barry, P.S.; Segal, C.C.; Shepanski, J.; Beiso, D.; Carman, S.L. Hyperion, a space-based imaging spectrometer. IEEE Trans. Geosci. Remote Sens. 2003, 41, 1160-1173. [CrossRef]

4. Van der Meer, F.D.; van der Werff, H.M.A.; van Ruitenbeek, F.J.A.; Hecker, C.A.; Bakker, W.H.; Noomen, M.F.; van der Meijde, M.; Carranza, E.J.M.; de Smeth, J.B.; Woldai, T. Multi- and hyperspectral geologic remote sensing: A review. Int. J. Appl. Earth Obs. Geoinf. 2012, 14, 112-128. [CrossRef]

5. Hewson, R.D.; Cudahy, T.J.; Huntington, J.F. Geologic and alteration mapping at Mt Fitton, South Australia, using ASTER satellite-borne data. In Proceedings of the 2001 IEEE Geoscience and Remote Sensing Symposium, Sydney, Australia, 9-13 July 2001; pp. 724-726.

6. Rowan, L.C.; Mars, J.C. Lithologic mapping in the Mountain Pass, California area using Advanced Spaceborne Thermal Emission and Reflection Radiometer (ASTER) data. Remote Sens. Environ. 2003, 84, 350-366. [CrossRef]

7. Mars, J.C.; Rowan, L.C. Spectral assessment of new ASTER SWIR surface reflectance data products for spectroscopic mapping of rocks and minerals. Remote Sens. Environ. 2010, 114, 2011-2025. [CrossRef]

8. Zhang, X.; Pamer, M.; Duke, N. Lithologic and mineral information extraction for gold exploration using ASTER data in the south Chocolate Mountains (California). ISPRS J. Photogramm. Remote Sens. 2007, 62, 271-282. [CrossRef] 
9. Rowan, L.C.; Hook, S.J.; Abrams, M.J.; Mars, J.C. Mapping hydrothermally altered rocks at Cuprite, Nevada, using the Advanced Spaceborne Thermal Emission and Reflection Radiometer (ASTER), a new satellite-imaging system. Econ. Geol. 2003, 98, 1019-1027. [CrossRef]

10. Bedini, E. Mineral mapping in the Kap Simpson complex, central east Greenland, using Hymap and ASTER remote sensing data. Adv. Space Res. 2011, 47, 60-73. [CrossRef]

11. Middleton, E.M.; Ungar, S.G.; Mandl, D.J.; Ong, L.; Frye, S.W.; Campbell, P.E.; Landis, D.R.; Young, J.P.; Pollack, N.H. The Earth Observing One (EO-1) satellite mission: Over a Decade in Space. IEEE J. Sel. Top. Appl. Earth Obs. Remote Sens. 2013, 6, 243-256. [CrossRef]

12. Green, R.O.; Pavri, B.E.; Chrien, T.G. On-orbit radiometric and spectral calibration characteristics of EO-1 Hyperion derived with an underflight of AVIRIS and in situ measurements at Salar de Arizaro, Argentina. IEEE Trans. Geosci. Remote Sens. 2003, 41, 1194-1203. [CrossRef]

13. Bergeron, M.; Hollinger, A.; Staenz, K.; Maszkiewicz, M.; Neville, R.A.; Qian, S.E.; Goodenough, D.G. Hyperspectral environment and resource observer (HERO) mission. Can. J. Remote Sens. 2008, 34, S1-S11. [CrossRef]

14. Guanter, L.; Kaufmann, H.; Segl, K.; Foerster, S.; Rogass, C.; Chabrillat, S.; Kuester, T.; Hollstein, A.; Rossner, G.; Chlebek, C.; et al. The EnMAP spaceborne imaging spectroscopy mission for earth observation. Remote Sens. 2015, 7, 8830-8857. [CrossRef]

15. Matsunaga, T.; Iwasaki, A.; Tsuchida, S.; Tanii, J.; Kashimura, O.; Nakamura, R.; Yamamoto, H.; Tachikawa, T.; Rokugawa, S. Current status of Hyperspectral Imager Suite (HISUI). In Proceedings of the 2014 IEEE International Geoscience and Remote Sensing Symposium (IGARSS), Quebec, QC, Canada, 13-18 July 2014.

16. Lopinto, E.; Ananasso, C. The Prisma Hyperspectral Mission. Available online: http://www.earsel.org/ symposia/2013-symposium-Matera/proceedings.php (accessed on 4 January 2016).

17. Lee, C.M.; Cable, M.L.; Hook, S.J.; Green, R.O.; Ustin, S.L.; Mandl, D.J.; Middleton, E.M. An introduction to the NASA Hyperspectral Infrared Imager (HyspIRI) mission and preparatory activities. Remote Sens. Environ. 2015, 167, 6-19. [CrossRef]

18. AVIRIS Web Site. Available online: http://aviris.jpl.nasa.gov (accessed on 16 February 2016).

19. MASTER Web Site. Available online: http://masterweb.jpl.nasa.gov (accessed on 16 February 2016).

20. Jennings, C.W.; Strand, R.G.; Rogers, T.H. Geologic Map of California, Scale 1:750,000; California Division of Mines and Geology: Piscataway, NJ, USA, 1977.

21. Jennings, O.P. Geologic Map of California: Salton Sea Sheet, Scale 1:250,000; California Division of Mines and Geology: Sacramento, CA, USA, 1967.

22. Bjornstad, S.; Alm, S.; Huang, W.; Tiedeman, A.; Frazier, L.; Page, C.; Sabin, A.; Veazey, D. An Update on Geothermal Energy Resource Investigations, Chocolate Mountains Aerial Gunnery Range, Imperial Valley, California. Trans. Geotherm. Resour. Counc. 2011, 35, 713-720.

23. New Gold Inc. Technical Report on the Mesquite Mine, Imperial County, California, USA; NI $43-101$ Report; Roscoe Postle Associates Inc.: Toronto, ON, Canada, 2014.

24. Jacobsen, C.E.; Grove, M.; Vućić, A.; Pedrick, J.N.; Ebert, K.A. Exhumation of the Orocopia Schist and associated rocks of southeastern California: Relative Roles of Erosion, Synsubduction Tectonic Denudation, and Middle Cenozoic Extension. Geol. Soc. Am. Spec. Pap. 2007, 419, 1-37.

25. Norris, R.M.; Norris, K.S. Algodones Dunes of southeastern California. Geol. Soc. Am. Bull. 1961, 72, 605-620. [CrossRef]

26. Lynch, D.K.; Hudnut, K.W.; Adams, P.M. Development and growth of recently-exposed fumarole fields near Mullet Island, Imperial County, California. Geomorphology 2013, 195, 27-44. [CrossRef]

27. Lynch, D.K.; Hudnut, K.W. The Wister mud pot lineament: Southeastward Extension or Abandoned Strand of the San Andreas Fault? Bull. Seismol. Soc. Am. 2008, 98, 1720-1729. [CrossRef]

28. Reath, K.A.; Ramsey, M.S. Exploration of geothermal systems using hyperspectral thermal infrared remote sensing. J. Volcanol. Geotherm. Res. 2013, 265, 27-38. [CrossRef]

29. Tratt, D.M.; Young, S.J.; Lynch, D.K.; Buckland, K.N.; Johnson, P.D.; Hall, J.L.; Westberg, K.R.; Polak, M.L.; Kasper, B.P.; Qian, J. Remotely sensed ammonia emission from fumarolic vents associated with a hydrothermally active fault in the Salton Sea Geothermal Field, California. J. Geophys. Res. 2011, 116, D21308. [CrossRef]

30. Schmitt, A.K.; Martin, A.; Stockli, D.F.; Farley, K.A.; Lovera, O.M. (U-Th)/He Zircon and archaeological ages for a late prehistoric eruption in the Salton Trough (California, USA). Geology 2013, 41, 7-10. [CrossRef] 
31. Wright, H.M.; Vazquez, J.A.; Champion, D.E.; Calvert, A.T.; Mangan, M.T.; Stelten, M.; Cooper, K.M.; Herzig, C.; Schriener, A. Episodic Holocene eruption of the Salton Buttes rhyolites, California, from paleomagnetic, U-Th, and Ar/Ar dating. Geochem. Geophys. Geosyst. 2015, 16, 1198-1210. [CrossRef]

32. Brothers, D.S.; Driscoll, N.W.; Kent, G.M.; Harding, A.J.; Babcock, J.M.; Baskin, R.L. Tectonic evolution of the Salton Sea inferred from seismic reflection data. Nat. Geosci. 2009, 2, 581-584. [CrossRef]

33. McGuire, J.J.; Lohman, R.B.; Catchings, R.D.; Rymer, M.J.; Goldman, M.R. Relationships among seismic velocity, metamorphism, and seismic and aseismic fault slip in the Salton Sea Geothermal Field region. J. Geophys. Res. Solid Earth 2015, 120, 2600-2615. [CrossRef]

34. Wei, S.J.; Avouac, J.P.; Hudnut, K.W.; Donnellan, A.; Parker, J.W.; Graves, R.W.; Helmberger, D.; Fielding, E.; Liu, Z.; Cappa, F.; et al. The 2012 Brawley swarm triggered by injection-induced aseismic slip. Earth Planet. Sci. Lett. 2015, 422, 115-125. [CrossRef]

35. Thompson, D.R.; Gao, B.C.; Green, R.O.; Roberts, D.A.; Dennison, P.E.; Lundeen, S.R. Atmospheric correction for global mapping spectroscopy: ATREM Advances for the HyspIRI Preparatory Campaign. Remote Sens. Environ. 2015, 167, 64-77. [CrossRef]

36. Orthorectified HyspIRI Preparatory Campaign Products. Available online: ftp://popo.jpl.nasa.gov/2013_ HyspIRI_Prep_Data/AVIRIS_HyspIRI_Simulated_Data_Products.readme (accessed on 21 December 2015).

37. Grigsby, S.P.; Hulley, G.C.; Roberts, D.A.; Scheele, C.; Ustin, S.L.; Alsina, M.M. Improved surface temperature estimates with MASTER/AVIRIS sensor fusion. Remote Sens. Environ. 2015, 167, 53-63. [CrossRef]

38. Littlefield, E.F.; Calvin, W.M. Geothermal exploration using imaging spectrometer data over Fish Lake Valley, Nevada. Remote Sens. Environ. 2014, 140, 509-518. [CrossRef]

39. Clark, R.N.; Swayze, G.A.; Wise, R.; Livo, E.; Hoefen, T.; Kokaly, R.; Sutley, S.J. USGS Digital Spectral Library Splib06a; U.S. Geological Survey: Reston, VA, USA, 2007.

40. Kruse, F.A.; Taranik, J.V.; Coolbaugh, M.; Michaels, J.; Littlefield, E.F.; Calvin, W.M.; Martini, B.A. Effect of reduced spatial resolution on mineral mapping using imaging spectrometry-examples using Hyperspectral Infrared Imager (HyspIRI)-simulated data. Remote Sens. 2011, 3, 1584-1602. [CrossRef]

41. Calvin, W.M.; Littlefield, E.F.; Kratt, C. Remote sensing of geothermal-related minerals for resource exploration in Nevada. Geothermics 2015, 53, 517-526. [CrossRef]

42. Vaughan, R.G.; Hook, S.J.; Calvin, W.M.; Taranik, J.V. Surface mineral mapping at Steamboat Springs, Nevada, USA, with multi-wavelength thermal infrared images. Remote Sens. Environ. 2005, 99, 140-158. [CrossRef]

43. Hewson, R.D.; Cudahy, T.J.; Mizuhiko, S.; Ueda, K.; Mauger, A.J. Seamless geological map generation using ASTER in the broken Hill-Curnamona province of Australia. Remote Sens. Environ. 2005, 99, 159-172. [CrossRef]

44. Rowan, L.C.; Mars, J.C.; Simpson, C.J. Lithologic mapping of the Mordor, NT, Australia ultramafic complex by using the Advanced Spaceborne Thermal Emission and Reflection Radiometer (ASTER). Remote Sens. Environ. 2005, 99, 105-126. [CrossRef]

45. Rowan, L.C.; Schmidt, R.G.; Mars, J.C. Distribution of hydrothermally altered rocks in the Reko Diq, Pakistan mineralized area based on spectral analysis of ASTER data. Remote Sens. Environ. 2006, 104, 74-87. [CrossRef]

46. Coolbaugh, M.F.; Kratt, C.; Fallacaro, A.; Calvin, W.M.; Taranik, J.V. Detection of geothermal anomalies using Advanced Spaceborne Thermal Emission and Reflection Radiometer (ASTER) thermal infrared images at Bradys Hot Springs, Nevada, USA. Remote Sens. Environ. 2007, 106, 350-359. [CrossRef]

47. Rockwell, B.W.; Hofstra, A.H. Identification of quartz and carbonate minerals across northern Nevada using ASTER thermal infrared emissivity data-Implications for geologic mapping and mineral resource investigations in well-studied and frontier areas. Geosphere 2008, 4, 218-246. [CrossRef]

48. Hook, S.J.; Dmochowski, J.E.; Howard, K.A.; Rowan, L.C.; Karlstrom, K.E.; Stock, J.M. Mapping variations in weight percent silica measured from multispectral thermal infrared imagery-Examples from the Hiller Mountains, Nevada, USA and Tres Virgenes-La Reforma, Baja California Sur, Mexico. Remote Sens. Environ. 2005, 95, 273-289. [CrossRef]

(C) 2016 by the authors; licensee MDPI, Basel, Switzerland. This article is an open access article distributed under the terms and conditions of the Creative Commons by Attribution (CC-BY) license (http:/ / creativecommons.org/licenses/by/4.0/). 